\title{
Marine sources of bromoform in the global open ocean - global patterns and emissions
}

\author{
I. Stemmler ${ }^{1,3}$, I. Hense ${ }^{1}$, and B. Quack ${ }^{2}$ \\ ${ }^{1}$ Institute for Hydrobiology and Fisheries Science, University of Hamburg, CEN, Hamburg, Germany \\ ${ }^{2}$ Geomar, Helmholtz Centre for Ocean Research, Kiel, Germany \\ ${ }^{3}$ Max Planck Institute for Meteorology, Hamburg, Germany \\ Correspondence to: I. Stemmler (irene.stemmler@uni-hamburg.de)
}

Received: 22 September 2014 - Published in Biogeosciences Discuss.: 7 November 2014

Revised: 27 February 2015 - Accepted: 2 March 2015 - Published: 25 March 2015

\begin{abstract}
Bromoform $\left(\mathrm{CHBr}_{3}\right)$ is one important precursor of atmospheric reactive bromine species that are involved in ozone depletion in the troposphere and stratosphere. In the open ocean bromoform production is linked to phytoplankton that contains the enzyme bromoperoxidase. Coastal sources of bromoform are higher than open ocean sources. However, open ocean emissions are important because the transfer of tracers into higher altitude in the air, i.e. into the ozone layer, strongly depends on the location of emissions. For example, emissions in the tropics are more rapidly transported into the upper atmosphere than emissions from higher latitudes. Global spatio-temporal features of bromoform emissions are poorly constrained. Here, a global three-dimensional ocean biogeochemistry model (MPIOMHAMOCC) is used to simulate bromoform cycling in the ocean and emissions into the atmosphere using recently published data of global atmospheric concentrations (Ziska et al., 2013) as upper boundary conditions. Our simulated surface concentrations of $\mathrm{CHBr}_{3}$ match the observations well. Simulated global annual emissions based on monthly mean model output are lower than previous estimates, including the estimate by Ziska et al. (2013), because the gas exchange reverses when less bromoform is produced in non-blooming seasons. This is the case for higher latitudes, i.e. the polar regions and northern North Atlantic. Further model experiments show that future model studies may need to distinguish different bromoform-producing phytoplankton species and reveal that the transport of $\mathrm{CHBr}_{3}$ from the coast considerably alters open ocean bromoform concentrations, in particular in the northern sub-polar and polar regions.
\end{abstract}

\section{Introduction}

Bromoform $\left(\mathrm{CHBr}_{3}\right)$ is one of the most abundant brominecontaining volatile halocarbons and is a considerable source of reactive bromine species in the atmosphere (e.g. Carpenter and Liss, 2000; Law and Sturges, 2007; Salawitch, 2006). Due to its lifetime of approximately 3-4 weeks (Moortgat et al., 1993; Law and Sturges, 2007), bromoform alters the bromine budget in both the troposphere and the stratosphere and can lead to ozone depletion with potential impacts on the radiation budget of the atmosphere (Hossaini et al., 2010; Saiz-Lopez et al., 2012).

Troposphere-stratosphere transport of short-lived volatile compounds (including bromoform) highly depends on the location of the emissions (Aschmann et al., 2009; Tegtmeier et al., 2012); thus the spatio-temporal quantification of emissions is essential for assessing its impact on atmospheric chemistry and climate. However, bromoform emissions are so far poorly constrained and represent a significant uncertainty in global atmospheric chemistry models (Hossaini et al., 2013). Bromoform has both natural and anthropogenic sources. Anthropogenic sources (e.g. desalination or disinfection of water; e.g. Allonier et al., 1999) are thought to contribute relatively little to the global emissions (Quack and Wallace, 2003). Natural bromoform synthesis in the open ocean is mainly related to phytoplankton (Moore et al., 1996; Lin and Manley, 2012). However, it is unclear whether bromoform is formed extra- or intracellularly. In any case, the enzyme bromoperoxidase drives the process in which bromide is oxidized in the presence of $\mathrm{H}_{2} \mathrm{O}_{2}$ followed by a halogenation of organic compounds (haloform reaction). There 
are indications of intracellular production; for example, some laboratory studies show that bromoform is released during phytoplankton growth (e.g. by diatoms; Moore et al., 1996; Hughes et al., 2013). In contrast, there is also evidence that bromoform is extracellularly produced, as the components that are necessary for bromoform production (dissolved organic compounds and the enzyme bromoperoxidase) may escape via cell lysis or exudation of phytoplankton (Lin and Manley, 2012; Wever and van der Horst, 2013).

Enhanced bromoform production during stress, as shown for macroalgae (e.g. Bondu et al., 2008), has not been demonstrated for phytoplankton. However, the amount of bromoform produced can be related to different phytoplankton species. Differences between typical open ocean microalgae, i.e. the coccolithophores (Emiliana and Calcidiscus) and diatoms (Chaetoceros), are rather small (within a factor of 2) (Colomb et al., 2008). These different phytoplankton groups show different global distribution patterns (O'Brien et al., 2013; Leblanc et al., 2012). In addition, open ocean bromoform may partly originate from coastal sources via lateral transport (Moore and Tokarczyk, 1993; Carpenter and Liss, 2000). In fact, the coastal sources can be much stronger than the open ocean source (Moore and Tokarczyk, 1993; Quack and Wallace, 2003; Carpenter et al., 2009; Liu et al., 2011). In these regions production occurs predominantly by macroalgae (Manley et al., 1992; Laturnus, 2001; Leedham et al., 2013). All these aspects are important to understand current open ocean concentrations and emissions, and to potentially project its future development under a changing climate. Here, we address the question of the impact of phytoplankton and lateral transport from the coast on open ocean bromoform concentrations. For this purpose we implement a refined version of the bromoform module of Hense and Quack (2009) into a marine biogeochemistry model (the Hamburg Ocean Carbon Cycle model HAMOCC: Ilyina et al., 2013) which is coupled to a global ocean general circulation model (the Max Planck Institute ocean model, MPIOM: Marsland et al., 2003). In a suite of present-day equilibrium simulations we investigate the contribution of bulk phytoplankton, diatom and non-diatom phytoplankton to bromoform production. We assess the relevance of $\mathrm{CHBr}_{3}$ advection from the coast and characterize emissions to the atmosphere based on simulated oceanic concentrations and observed atmospheric concentrations.

\section{Material and methods}

\subsection{Bromoform module}

We use the bromoform cycling module as presented in Hense and Quack (2009). They used the module within the onedimensional water column model GOTM (General Ocean Turbulence Model; Umlauf et al., 2005) together with a simple nutrients-phytoplankton-zooplankton-detritus (NPZD)- type ecosystem model to represent conditions during Meteor cruise M55 in the Cabo Verde region. Here, we use the module within the three-dimensional ocean general circulation model MPIOM (Marsland et al., 2003) that includes the biogeochemistry model HAMOCC (Ilyina et al., 2013). Only mean features of the bromoform module and modifications to the earlier parameterization are presented; details on the original parameterizations can be found in Hense and Quack (2009).

Bromoform B (in $\mathrm{mmolm}^{-3}$ ) in the model is updated at every time step following production, decay, advection, diffusion, and gas exchange with the atmosphere. The only bromoform production process considered in the current study is $\mathrm{CHBr}_{3}$ production during phytoplankton growth. We do not consider bromoform synthesis linked to phytoplankton sinks, i.e. the extracellular production of bromoform. Hense and Quack (2009) implemented this process and did not find differences in $\mathrm{CHBr}_{3}$ concentrations, because phytoplankton sinks are closely co-located with its sources. This is also the case in HAMOCC; thus large-scale features will be the same, despite moderate differences in timing of maximum bromoform production. As the biogeochemistry model does not resolve plankton functional groups, we can not directly calculate species- (or group-) specific bromoform production. However, the contribution of diatoms can be assessed indirectly from the availability of silicate, as done previously for fractionating carbon export production and for parameterizing dimethylsulfide production (Kloster et al., 2006; Ilyina et al., 2013). It is assumed that diatoms grow faster than other phytoplankton groups; thus, whenever silicate is available, diatoms are dominant, whereas residual plankton groups dominate under silicate-limiting conditions. The bromoform production ratio $\beta$ is derived from the bulk bromoform production ratio $\beta_{0}$ :

$\beta=\beta_{0} \cdot\left(\frac{\mathrm{fac} 1 \cdot \mathrm{Si}(\mathrm{OH})_{4}}{K_{\mathrm{phy}}^{\mathrm{Si}(\mathrm{OH})_{4}}+\mathrm{Si}(\mathrm{OH})_{4}}+\frac{\mathrm{fac} 2 \cdot K_{\mathrm{phy}}^{\mathrm{Si}(\mathrm{OH})_{4}}}{K_{\mathrm{phy}}^{\mathrm{Si}(\mathrm{OH})_{4}}+\mathrm{Si}(\mathrm{OH})_{4}}\right)$,

where $K_{\text {phy }}^{\mathrm{Si}(\mathrm{OH})_{4}}$ denotes the half-saturation constant for silicate $\left(\mathrm{Si}(\mathrm{OH})_{4}\right)$ uptake. We test different factors fac 1 and fac 2 for the relative contribution of diatoms and non-diatom phytoplankton (see Sect. 2.3).

Bromoform degradation processes considered in the model are photolysis, halide substitution, hydrolysis, and bacterial degradation during nitrification. We omit degradation during remineralization of detritus in this study, because Hense and Quack (2009) showed that it leads to unrealistic accumulation of bromoform in the deep ocean. An increase in the degradation rate did not solve this issue but instead led to too low subsurface maxima. With regard to degradation by ammonium oxidizing bacteria, we introduce one modification. As it was shown for freshwater nitrifiers that these bacteria can oxidize volatile halogenated organic compounds (including $\mathrm{CHBr}_{3}$; see e.g. Sayavedra-Soto et al., 2010) dur- 
ing oxidation of ammonium hydroxylamine, it seems reasonable to exclude this process for low-oxygen conditions. Therefore, a threshold of $\left[\mathrm{O}_{2}\right]>50 \mu \mathrm{mol} \mathrm{m}{ }^{-3}$ for the occurrence of this process is implemented.

Hense and Quack (2009) represented halide substitution and hydrolysis as one first-order decay process with a half-life of 4.37 years. As both processes are strongly temperature-dependent and follow different kinetics, hydrolysis and halogen substitution are implemented in the current study as separate sinks. The former is implemented as a firstorder decay process with a temperature-dependent decay rate $l_{\text {hyd }}$ :

$S=l_{\text {hyd }}(T) \cdot B$.

Washington (1995) reviewed hydrolysis rates of organic halogens and suggested the following temperature dependence of the basic hydrolysis rate $k_{\mathrm{B}}$ in $\operatorname{mol~min}^{-1}$ :

$k_{B}=A_{1} \cdot \exp \left(\frac{-E_{\mathrm{A}}}{R T}\right)$,

with $A_{1}=1.23 \times 10^{17} \mathrm{~mol} \mathrm{~min}^{-1}, E_{\mathrm{A}}=107300 \mathrm{~J} \mathrm{~mol}^{-1}$, $R=8.314 \mathrm{~J} \mathrm{~K}^{-1} \mathrm{~mol}^{-1}$, and $T$ the seawater temperature in $\mathrm{K}$. The hydrolysis rate then follows from

$l_{\text {hyd }}=k_{\mathrm{B}} \cdot\left[\mathrm{OH}^{-}\right]$,

where $\left[\mathrm{OH}^{-}\right]$is calculated from the dissociation product of water and the hydrogen ion concentration, which are part of the carbonate chemistry formulation in HAMOCC (which uses the formulation of Roy et al., 1993).

Also, halide substitution is implemented as a first-order degradation process with a temperature-dependent rate constant, $\left(l_{\text {subst }}\right)$

$S=l_{\text {subst }}(T) \cdot B$.

The rate is chosen to vary exponentially and represents a half-life of $\tau_{1 / 2}=5$ years at $25^{\circ} \mathrm{C}$ and $\tau_{1 / 2}=74$ years at $2{ }^{\circ} \mathrm{C}$ (Geen, 1992).

$l_{\text {subst }}=l_{\text {ref }} \exp \left(A_{2} \cdot\left(\frac{1}{T_{\text {ref }}}-\frac{1}{T}\right)\right)$,

with $\quad l_{\text {ref }}=7.33 \times 10^{-10} \mathrm{~s}^{-1} \quad$ at $\quad T_{\text {ref }}=298 \mathrm{~K}, \quad A_{2}=$ $12507.13 \mathrm{~K}$, and $T$ the seawater temperature in $\mathrm{K}$.

In Hense and Quack (2009) $\mathrm{CHBr}_{3}$ gas exchange with the atmosphere was calculated from the two-film model assuming it is controlled by the water side:

$F_{\text {air-sea }}=k_{\mathrm{w}} \cdot\left(B-\frac{c_{\mathrm{a}}}{H}\right)$.

Hence, the flux was calculated from atmospheric concentrations $c_{\mathrm{a}}$, solubility (Henry's law constant $H$; Moore et al., 1995), bulk surface water concentrations $(B)$, and a transfer velocity $\left(k_{\mathrm{w}}\right)$. We modify the description of the transfer velocity given by Nightingale et al. (2000) to resolve the temperature dependence of the Schmidt number $S c_{\mathrm{CHBr}_{3}}$ (Quack and Wallace, 2003):

$k_{\mathrm{w}}=\left(0.222 u^{2}+0.33 u\right) \cdot \sqrt{\frac{660}{S c_{\mathrm{CHBr}_{3}}}}$,

$S c_{\mathrm{CHBr}_{3}}=4662.8-319.45 T+9.9012 T^{2}-0.1159 T^{3}$.

In the equations, $u$ denotes wind speed $\left(\mathrm{m} \mathrm{s}^{-1}\right)$ and $T$ temperature $(\mathrm{K})$.

\subsection{Observations}

$\mathrm{CHBr}_{3}$ observations are taken from the supporting information of Ziska et al. (2013), who extrapolated cruise data submitted to the HalOcAt database (https://halocat.geomar.de) into a global gridded field of bromoform concentrations and calculated emissions. Ziska et al. (2013) provide gridded data derived from a robust fit (RF) method and ordinary leastsquares (OLS) regression. The largest difference in these methods is in the treatment of outliers.

Gridded atmospheric mixing ratios are used as boundary conditions for the model after conservative spatial interpolation onto the model grid. We use the data derived from the RF method that is less sensitive to outliers. For the model evaluation we use the individual ship cruise data to avoid the influence of patterns arising from extrapolation of the sparse data matrix. We compare observed data from a particular month to modelled monthly means. The exact origin of the individual data can be identified from the supporting information in Ziska et al. (2013).

The observation-based net primary productivity (NPP) that we use in the model evaluation was downloaded from http://www.science.oregonstate.edu/ocean.productivity/ index.php (accessed in June 2014). NPP is calculated from NASA's SeaWIFS (Sea-viewing Wide Field-of-view Sensor) level 3 data (PAR and Chl $a$ ) and NOAA's AVHRR (Advanced Very High Resolution Radiometer) sea surface temperature for 1997-2009 using the Vertically Generalized Productivity Model (VGPM; Behrenfeld and Falkowski, 1997).

\subsection{Model setup}

Seven model experiments are set up to assess different aspects of bromoform cycling (Table 1). Of these, four experiments are designed to study bromoform synthesis by phytoplankton. All of these experiments use the climatological atmospheric concentrations of Ziska et al. (2013) as upper boundary conditions and resolve all other bromoform cycling processes as described above. The reference experiment Ref uses the constant bulk bromoform production ratio derived from a laboratory study with diatoms (Moore et al., 
1996; Hense and Quack, 2009). For usage in HAMOCC, this ratio is converted from nitrogen to phosphorus units using a constant Redfield ratio ( $\mathrm{N}: \mathrm{P}=16: 1)$. Following Colomb et al. (2008) we derive a factor of about 2 in the mean bromoform production ratio between the groups of the open ocean microalgae, i.e. the coccolithophores (Emiliana and Calcidiscus) and the diatom (Chaetoceros). As almost nothing is known about other phytoplankton groups (e.g. little on Baltic cyanobacteria (Karlsson et al., 2008) and nothing on flagellates), we test both a lower and a higher production ratio by diatoms and residual (non-diatom) phytoplankton. In the experiment Dia, the production ratio by diatoms is modified to be half that of residual plankton, i.e. fac $1=0.5$ and fac $2=1$. In the experiment NDia, the opposite is implemented, i.e. production by non-diatoms is reduced: fac $1=1$ and fac $2=0.5$. Additionally, an experiment (Half) is conducted in which the constant bulk production ratio is only half of that in Ref in order to separate the impact of a pure reduction of the global rate from fractionation among phytoplankton groups.

To test the hypothesis that open ocean bromoform is produced at the coast and advected to the open ocean, we conduct two joint experiments. In both experiments we eliminate the production of bromoform by phytoplankton, while we use the same atmospheric boundary conditions as in Ref. In the first one (Coast) we prescribe a bromoform concentration of $80 \mathrm{pmolL}^{-1}$ in waters shallower than $200 \mathrm{~m}$. We choose this artificial approach as it is impractical to resolve coastal sources (i.e. macroalgae with tide-dependent bromoform release, release from benthic algae and seagrass) explicitly in a global model with approximately $1.5^{\circ}$ horizontal resolution (curvilinear grid). As a result of the constant atmospheric boundary conditions, a flux from air to sea takes place because no bromoform is produced offshore. To quantify this bromoform source to the ocean, we perform a second experiment without prescribed bromoform on the shelf, Equi (which stands for equilibrium with the atmosphere). The comparison of Coast and Equi allows us to assess the relevance of lateral transport of bromoform from the coast to the open ocean.

An additional experiment is performed to address the effect of variability in the atmospheric concentrations. The lifetime of bromoform in air leads to a distinct seasonal cycle in atmospheric mixing ratios (e.g. Beyersdorf et al., 2010; Hossaini et al., 2013). The additional experiment, Seas-at, differs from Ref only in the atmospheric boundary conditions for bromoform gas exchange. In Seas-at, atmospheric boundary conditions follow a seasonal cycle. We derive that seasonal cycle from the surface ocean concentrations calculated in experiment Ref, because the extrapolated fields of Ziska et al. (2013) do not resolve temporal variability. In particular, the ratio between seawater concentration monthly means and their annual mean is used to construct the monthly means of atmospheric concentrations from the climatological mean. We thereby assume for simplicity that dynamics of atmo- spheric bromoform are controlled by oceanic concentrations. This is possible when the ocean is oversaturated with $\mathrm{CHBr}_{3}$ and $\mathrm{CHBr}_{3}$ is not accumulating in air.

For all simulations the model restarts from a 1000-year spin-up under pre-industrial conditions $\left(\mathrm{CO}_{2}=278 \mathrm{ppm}\right)$ followed by a 200-year spin-up under present-day conditions $\left(\mathrm{CO}_{2}=353 \mathrm{ppm}\right)$. Following these spin-ups the model experiments are run into steady state (starting from a constant $\mathrm{CHBr}_{3}$ concentration of $0.01 \mathrm{pmolL}^{-1}$ ). The model results are analysed for the last year of the simulation, when surface waters down to $500 \mathrm{~m}$ are in quasi-steady state. All experiment use NCEP 6-hourly forcing (Behringer and Xue, 2004) interpolated to the model time step of $72 \mathrm{~min}$ and monthly mean model output is analysed. In the following, whenever we use the term "model", we are referring to MPIOMHAMOCC.

\section{Results and discussion}

\subsection{Simulated open ocean sources and sinks of bromoform}

The aim of the study is to investigate the impact of planktonic production and lateral transport on bromoform surface concentration patterns and on sea-air gas exchange. The spatial distribution of bromoform in seawater reflects the balance between sources (production and uptake from the atmosphere) and losses via outgassing and degradation. In the experiments that include planktonic production of bromoform (Ref, Half, Dia, NDia, Seas-at), large-scale structures of surface concentrations are controlled by this process: maxima occur in biologically productive regions (e.g. in upwelling regions) and minima are located in the oligotrophic subtropical gyres in the Pacific and Atlantic Ocean (Figs. 1a, d and $2 \mathrm{a}, \mathrm{d})$. A reduction of the bulk production ratio of bromoform relative to primary production (Half) leads to a reduction of bromoform concentrations almost everywhere, apart from regions with uptake of bromoform from the atmosphere (e.g. the Southern Ocean and the northern extratropics in the local winter seasons, Fig. 1c and f). Lower marine $\mathrm{CHBr}_{3}$ production leads here to lower surface ocean concentrations during the phytoplankton bloom and thus a larger difference between seawater and atmospheric concentrations and hence enhanced uptake from the atmosphere, which in turn leads to higher surface seawater concentrations after the phytoplankton bloom. Similarly, differences between Ref and Seas-at are highest where the seasonal cycle of $\mathrm{CHBr}_{3}$ surface concentrations is pronounced, particularly in the extratropics, where the variability of bromoform production is strong (Figs. 1a, b, d, e; e.g. around $50^{\circ} \mathrm{N}$ ). This is because the seasonal cycle of the atmospheric forcing field in Seas-at is derived from the sea surface concentrations. Atmospheric concentrations higher than the climatological mean lead to a reduction of the flux and subsequently higher seawater 
Table 1. Model experiments. All experiments consider the degradation processes described in Sect. 2.1.

\begin{tabular}{lcccccc}
\hline & \multicolumn{2}{c}{$\mathrm{CHBr}_{3}$ production } & & \multicolumn{3}{c}{ Boundary conditions } \\
\cline { 2 - 3 } \cline { 5 - 7 } & $\begin{array}{c}\text { Diatoms } \\
\text { fac1 }\end{array}$ & $\begin{array}{c}\text { Non-diatoms } \\
\text { fac2 }\end{array}$ & & $\begin{array}{c}\text { Atmospheric } \mathrm{CHBr}_{3}\left(c_{\mathrm{a}}\right) \\
\text { climatological }\end{array}$ & $\begin{array}{c}\text { Prescribed coastal } \mathrm{CHBr}_{3} \\
\text { monthly }\end{array}$ & $<200{\mathrm{~m} 80 \mathrm{pmol} \mathrm{L}^{-1}}^{2}$ \\
\hline Ref & 1.0 & 1.0 & & + & - & - \\
Dia & 0.5 & 1.0 & & + & - & - \\
NDia & 1.0 & 0.5 & & + & - & - \\
Half & 0.5 & 0.5 & & + & - & - \\
Coast & 0.0 & 0.0 & & + & - & - \\
Equi & 0.0 & 0.0 & & + & - & - \\
Seas-at & 1.0 & 1.0 & & - & + & - \\
\hline
\end{tabular}

concentrations. A comparison of the experiments Ref and Equi, in which the only bromoform source is uptake from the atmosphere, reveals that uptake is particularly relevant in higher latitudes (Fig. S1 in the Supplement), where it can deliver more than $70 \%$ of the bromoform in surface seawater (not shown). In the polar regions bromoform production in the model is very low, as primary production is limited by light availability even during summer because of the sea ice. However, particularly in this specific region, uncertainties are large and bromoform cycling is not well captured in the model. First, this is because of the importance of uptake from the atmosphere. Our stand-alone ocean model is forced by extrapolated atmospheric bromoform concentrations from Ziska et al. (2013), where data from $\mathrm{CHBr}_{3}$ measurements are sparse. Second, our model does not consider a potentially important source process: production within sea ice and subsequent discharge into seawater during melting or by diffusion through brine channels (Mattson et al., 2012; Granfors et al., 2013).

As mentioned above, simulated bromoform distribution patterns mainly follow the patterns of simulated primary productivity. In the experiments Dia and NDia, a relative reduction of the bromoform production ratio for diatom (Dia) or residual phytoplankton (NDia) dominance by a factor of 2 is implemented. As a consequence of silicate availability the model predicts largest diatom abundances in the northern and southern extratropics (Fig. $2 \mathrm{~b}$ and e) and non-diatom phytoplankton in the lower latitudes (Fig. 2c and f). This distribution of diatoms is in line with the one predicted by models with explicit implementation of functional phytoplankton groups (e.g. Gregg and Casey, 2007) or diagnosed from satellite retrievals (Bracher et al., 2009). As a direct consequence of the model configuration, the bromoform production in both experiments is lower than in the experiment Ref, and bromoform concentrations are consequently lower. Compared to the uniform reduction of the bulk production rate in Half, concentrations are of course higher in regions in which the phytoplankton group with the unchanged (i.e. not reduced) production ratio dominates (Fig. 2). Similar to experiment Half, the reduction of the production rate in Dia leads to a reduction of the global bromoform inventory (Table 2), as diatoms dominate in productive regions. When focusing on certain regions, though, differences in the two approaches become apparent, e.g. in lower latitudes where nondiatom species dominate and the bromoform production (and concentration) is hence higher in Dia than in Half.

Primary production depends on light, temperature, and nutrient availability. Therefore in some ocean regions, such as the oligotrophic subtropical gyres, where surface nutrient concentrations are very low, production maxima are located in intermediate waters (at approximately $50-80 \mathrm{~m}$ ). In most open ocean regions, though, bromoform production maxima in the model are located within the upper mixed layer (Fig. 3). This suggests that seasonal mixing with deeper ocean layers, i.e. the dynamics of the mixed layer depth, play only a minor role in shaping the temporal evolution of bromoform surface concentrations. However, in regions with subsurface production maxima in summer, like the subtropical North Atlantic, the deepening of the mixed layer in winter mixes bromoform upwards and leads to surface maxima that do not correspond to surface production maxima (as also described in Hense and Quack, 2009).

The experiments Coast and Equi are designed to study lateral transport of bromoform from the coast to the open ocean within its lifetime. The mean global $\mathrm{CHBr}_{3}$ residence time in steady state in the experiments with planktonic production is approximately 200 days (Table 2). The global residence time does not reflect the local lifetime of bromoform at certain water depths or locations. At the global scale the residence time is dominated by gas exchange ( $\tau \approx 250$ days, Table 2); the residence time with regard to degradation is much longer ( $\tau \approx 1100$ days, Table 2 ). Thus, the lifetime within the mixed layer is much shorter than in the deeper ocean. However, it could be still long enough to allow for considerable transport of bromoform from the coast to the open ocean. In the experiment Coast, bromoform is reset to a concentration of $80 \mathrm{pmolL}^{-1}$ in waters shallower than $200 \mathrm{~m}$ at each model time step. The comparison between Coast and Equi allows us to assess the relevance of lateral transport, as Equi accounts for the contribution of uptake from air in pristine 

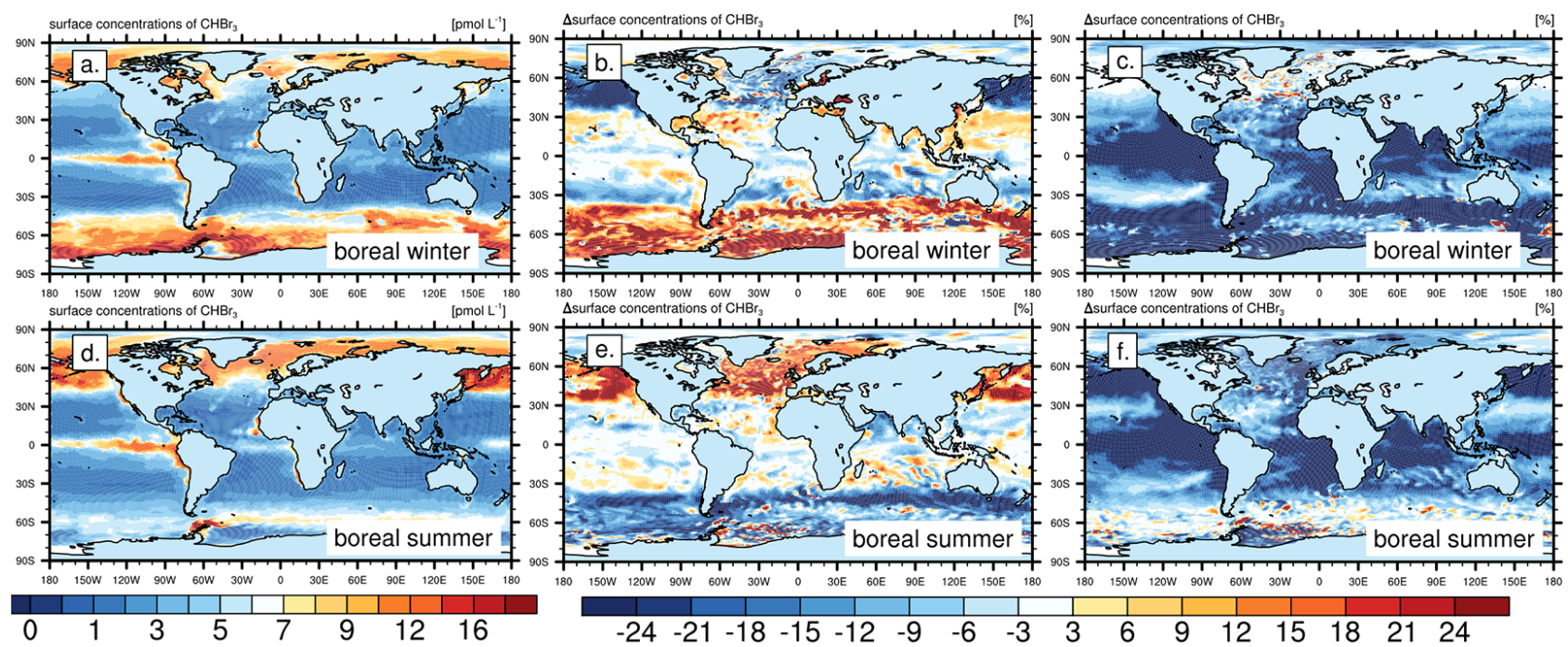

Figure 1. Mean surface bromoform concentrations $\left(\mathrm{pmolL}^{-1}\right)$ in experiment Ref in boreal winter (a) and boreal summer (d) and the percentage difference (e.g. $\left.100 \cdot \frac{\text { Seas-at-Ref }}{\text { Ref }}\right)$ of Seas-at $(\mathbf{b}, \mathbf{e})$ and Half $(\mathbf{c}, \mathbf{f})$ in the same season.
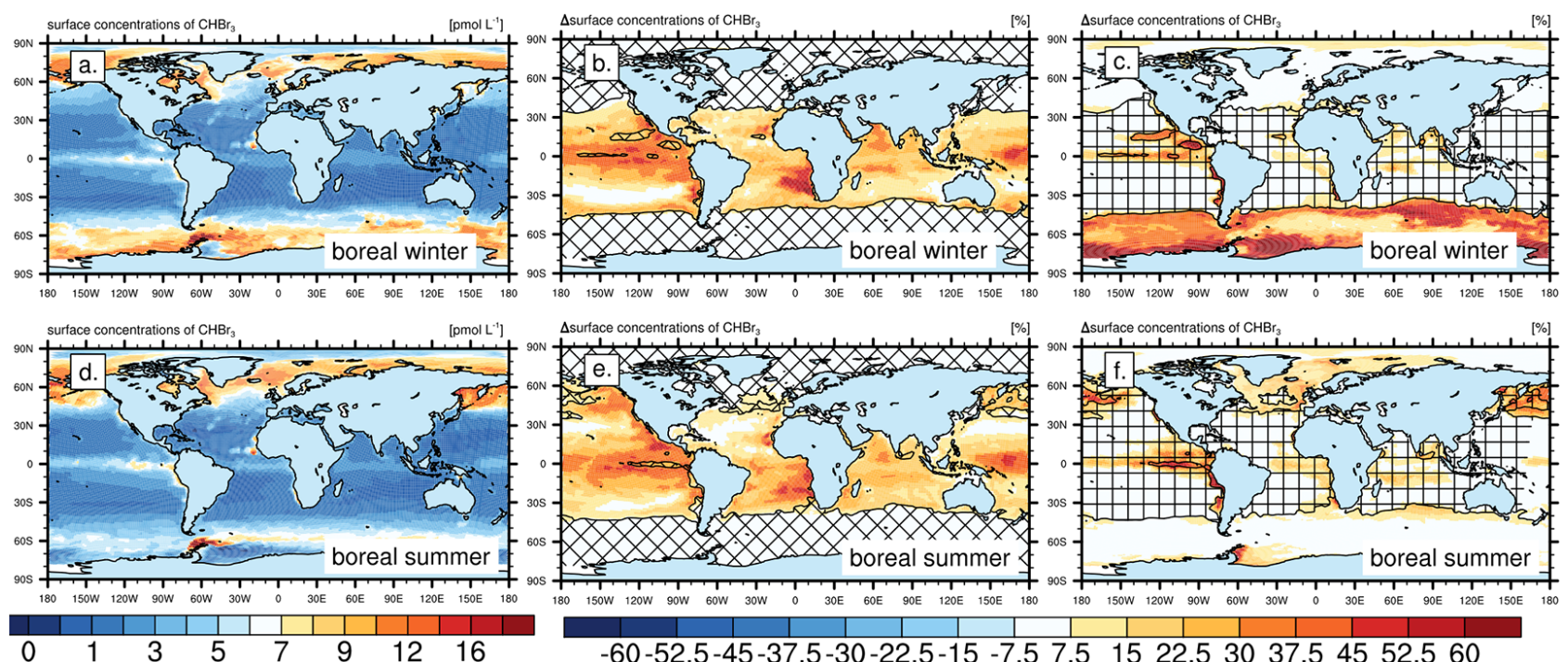

-60-52.5 - $45-37.5-30-22.5-15$-7.5 7.5 1522.53037 .54552 .560

Figure 2. Mean surface bromoform concentrations $\left(\mathrm{pmolL}^{-1}\right)$ in experiment Half in boreal winter (a) and boreal summer $(\mathbf{d})$ and the percentage difference (e.g. 100 . Dia-Half $)$ of Dia (b, e) and NDia (c, f) in the same season. Mesh patterns show regions where the fraction of diatoms $(\mathbf{b}, \mathbf{e})$ or non-diatoms $(\mathbf{c}, \mathbf{f})$ in bulk phytoplankton dominates (i.e. fraction $>0.5$ ) (inclined mesh for diatoms, straight mesh for non-diatoms).

open ocean waters. As expected, lateral transport from shelf regions is particularly relevant in the Arctic surface ocean (Figs. 4c, f and 5), because the Arctic Sea is semi-enclosed by land and outgassing is low at cold temperatures. In contrast, the surface concentrations in the open Pacific Ocean are least influenced by coastal bromoform. Our chosen value of $80 \mathrm{pmolL}^{-1}$ is an arbitrary value; however, it is more than 15 times higher compared to the mean open ocean concentration and therefore high enough to roughly represent the gradient between open ocean coastal regions. In comparison to Ref, most open ocean regions in the Atlantic and Pa- cific show lower surface concentrations in Coast (not shown). However, even in deep open ocean waters (water depths $>$ $1500 \mathrm{~m}$ ), surface bromoform concentrations reach 10-30\% of the coastal value in $10 \%$ of the model grid cells (Figs. 5 and $4 \mathrm{c}, \mathrm{f})$. Thus, in the North Atlantic, downstream of high coastal production a considerable fraction of open ocean surface concentrations may be attributed to lateral transport of bromoform. 
Table 2. Simulated global annual bromoform production and loss $\left(\mathrm{Gmol} \mathrm{CHBr}_{3} \mathrm{yr}^{-1}\right)$, inventory $\left(\mathrm{Gmol} \mathrm{CHBr}_{3}\right)$, and residence time (days); the first number refers to gas exchange and the second number to degradation

\begin{tabular}{lrrrrr}
\hline Process & Ref & Seas-at & Half & Dia & NDia \\
\hline Uptake & 0.018 & 0.016 & 0.024 & 0.022 & 0.019 \\
Outgassing & 0.3142 & 0.311 & 0.149 & 0.22 & 0.24 \\
Planktonic source & 0.37 & 0.37 & 0.18 & 0.26 & 0.29 \\
Degradation & 0.069 & 0.066 & 0.057 & 0.063 & 0.063 \\
Inventory & 0.215 & 0.205 & 0.1822 & 0.1966 & 0.200 \\
Residence times $\tau^{\mathrm{a}}($ days $)$ & 205 & 197 & 322 & 253 & 241 \\
$\left(\tau_{\text {gasx }}^{\mathrm{b}}, \tau_{\text {degr }}^{\mathrm{c}}\right)($ days $)$ & $(249,1141)$ & $(239,1124)$ & $(445,1167)$ & $(326,1144)$ & $(304,1161)$ \\
\hline
\end{tabular}

a: $\tau=\frac{1}{\frac{1}{\tau_{\text {degr }}}+\frac{1}{\tau_{\text {gasx }}}} ;$ b: $\tau_{\text {gasx }}=\frac{\text { inventory }}{\text { outgassing }} ;$ c: $\tau_{\text {degr }}=\frac{\text { inventory }}{\text { degradation }}$
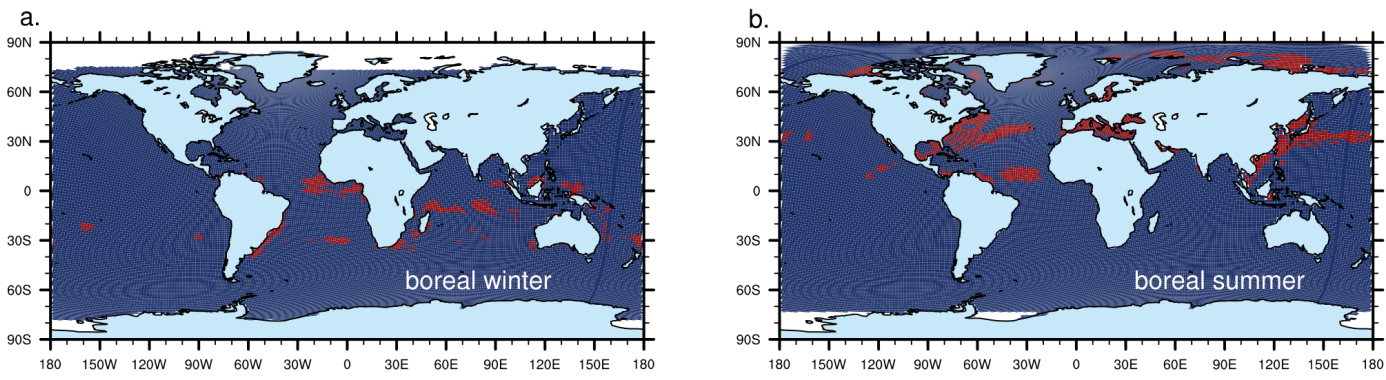

within mixed layer below mixed layer

Figure 3. Location of bromoform production maxima in Ref: within or below mixed layer for boreal winter (a) and boreal summer (b). The mixed-layer depth is defined as the depth where a density $\left(\sigma_{\mathrm{T}}\right)$ difference of 0.125 relative to the surface value occurs.

\subsection{Evaluation of simulated surface concentrations}

The evaluation of simulated surface concentrations is clustered regionally; that is, the Atlantic, the Pacific, the Southern Ocean, and the Arctic Ocean are discussed separately.

\section{Atlantic Ocean}

Simulated surface concentrations in the Atlantic show a distinct spatial and temporal pattern. The temporal coverage of bromoform observations does not allow for an extensive evaluation of the temporal evolution of bromoform concentrations. The spatial coverage, however, is high enough to compare spatial, in particular latitudinal, features of the $\mathrm{CHBr}_{3}$ distribution. Data from three cruises allow us to evaluate the latitudinal gradient in the Atlantic: Polarstern cruise Blast 2 (Butler et al., 2007), Polarstern cruise ANT X/1 (Schall et al., 1997), and Polarstern cruise ANT XVII/1 (Chuck et al., 2005). Blast 2 (Fig. S6) and ANT X/1 (Fig. S14) cross the Atlantic from the northeast (off the European continent and North Africa) to South America in boreal autumn (October, November). The cruise ANT XVII/1 leads along the African coast from the subtropical North to the South Atlantic in August (Fig. S24). Roughly, both simulated and observed concentrations in autumn show high bromoform levels in the extratropics $\left(3-10 \mathrm{pmol} \mathrm{L}^{-1}\right)$, a decrease towards the subtropics (approximately $1 \mathrm{pmolL}^{-1}$ ), and a peak at the Equator (approximately 2 pmol L $^{-1}$, Figs. S14 and S24). In comparison to the Blast 2 cruise (Butler et al., 2007), the general distribution pattern is well represented in all experiments with an open ocean bromoform source, but the model overestimates the peak at the Equator (factor of 1.35-1.8 between model and observation), concentrations at the secondary peak at $10-20^{\circ} \mathrm{N}$ (factor of $1.95-2.6$ between model and observation), and concentrations close to the Patagonian Shelf (factor of 2-3; Fig. S6). There are observations of bromoform at the Equator in the same season that show higher bromoform levels $\left(8-14\right.$ pmol L $^{-1}$; Quack et al., 2004). Both maxima (at the Equator and in the subtropics) are caused by spatial primary production maxima triggered by nitrate availability. Our parameterization of $\mathrm{CHBr}_{3}$ production strongly relies on the quality of simulated spatiotemporal distribution of primary production. Primary production is not a primary target parameter of HAMOCC, which is designed to capture global features of the carbon cycle; for example, it is configured to reproduce realistic organic carbon export rates. We simulate a global net primary productivity (NPP) of $59.3 \mathrm{GtCyr}^{-1}$, which is in the 


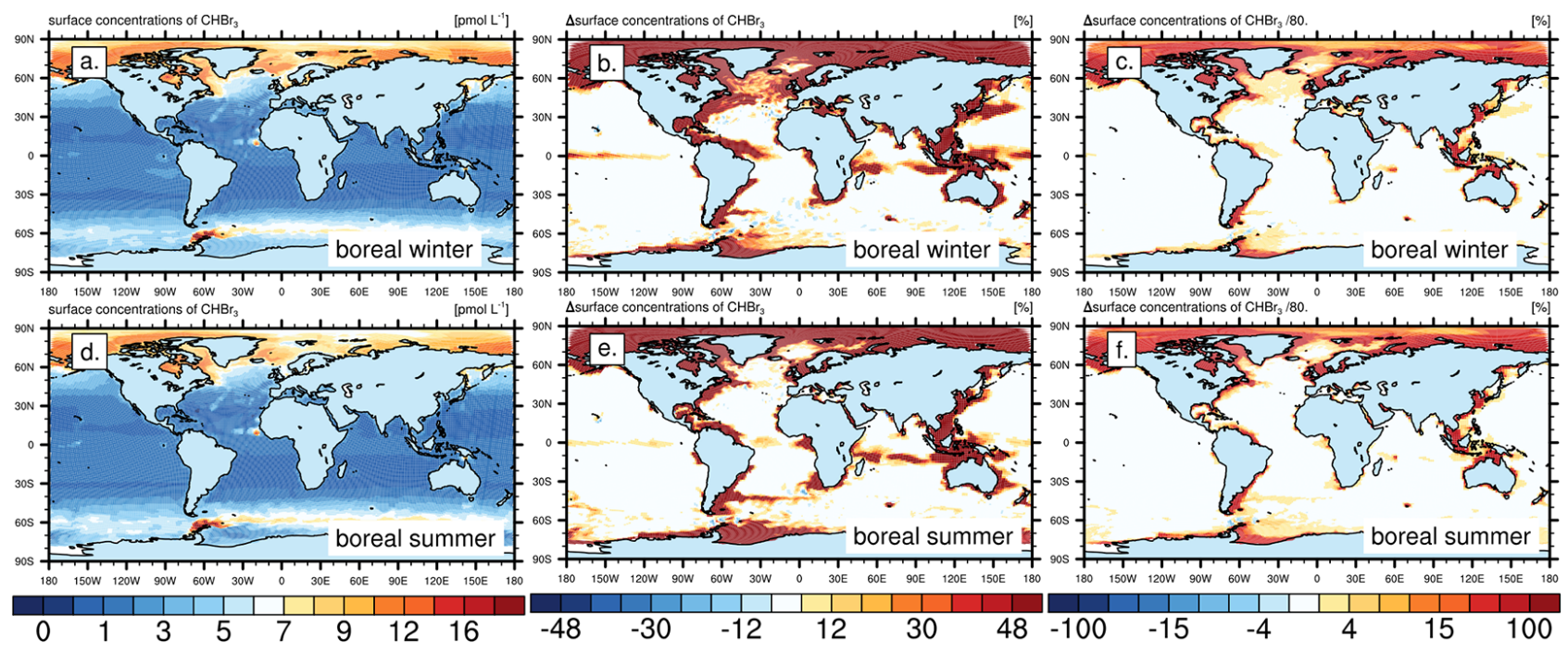

Figure 4. Mean surface bromoform concentrations $\left(\mathrm{pmolL}^{-1}\right)$ in experiment Equi in boreal winter (a) and boreal summer $(\mathbf{d})$ and the percentage difference (e.g. 100 $\left.\frac{\text { Coast-Equi }}{\text { Equi }}\right)$ of experiment Coast $(\mathbf{b}, \mathbf{e})$ and $100 \cdot \frac{\text { Coast-Equi }}{80 \mathrm{pmol} \mathrm{L}^{-1}}(\mathbf{c}, \mathbf{f})$ in the same season.
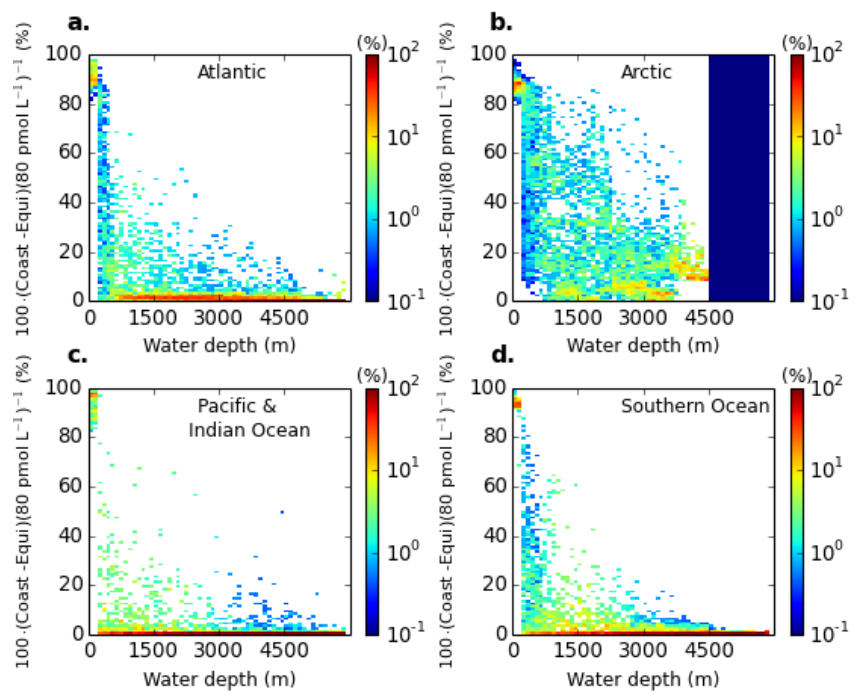

Figure 5. Histograms of $100 \cdot \frac{\text { Coast-Equi }}{80 \mathrm{pmolL}^{-1}}$ surface concentrations [\%] for different local water depths in the Atlantic Ocean (a), Arctic Ocean (b), Pacific and Indian Ocean (c), and Southern Ocean (d).

range of published estimates (e.g. $52 \mathrm{GtC} \mathrm{yr}^{-1}$ - Westberry et al., 2008; NPP $=51 \pm 10 \mathrm{GtCyr}^{-1}-$ Carr et al., 2006). Observations of primary production are not available from the ship cruises when $\mathrm{CHBr}_{3}$ was measured. Therefore we compare the simulated primary production to a NPP product derived from satellite-based ocean colour data (details in Sect. 2.2) to evaluate bromoform production in more detail. Indeed, the simulated primary production exceeds the observed NPP in locations of equatorial upwelling in boreal summer (Fig. S3f). However, direct comparison along the ship track of Blast 2 indicates that this overestimation is just slightly higher than the observed maximum (650 vs. $590 \mathrm{mg} \mathrm{C} \mathrm{m}^{-2} \mathrm{~d}^{-1}$, Fig. S7). The secondary maximum close to $15^{\circ} \mathrm{N}$ is within the range of observed primary production. This indicates either that conditions during the cruise are not captured in this satellite-based estimate or that the implementation of the production process as a linear function of plankton growth does not fully capture characteristics of bromoform production. Furthermore, our model experiments are designed to reflect present-day conditions in the open ocean rather than to represent historic conditions. In the experiments with a reduced bromoform production rate (Half, Dia, NDia), the simulated bromoform concentrations $\left(2-2.7\right.$ pmol L$^{-1}$ vs. 3.6 pmol L$^{-1}$ in Ref) in the northern subtropical Atlantic are slightly closer to observations, which are around $1.0 \mathrm{pmol} \mathrm{L}^{-1}$. This is also true when looking into the broader latitudinal bands (Fig. S5); in all bands of $50^{\circ} \mathrm{S}-20^{\circ} \mathrm{N}$ and $40-60^{\circ} \mathrm{N}$, bromoform seems to be better represented with a reduced production rate. The comparison between other individual ship cruises, e.g. MSM 18/3 (Fig. S12) and DRIVE (Fig. S10), shows that this method (reduction of the production ratio) does not improve uniformly the model results. Ideally, simulated primary productivity, production rate, and even species composition need to reflect the conditions during the cruise to obtain the best possible representation of bromoform distribution patterns.

\section{Pacific}

To evaluate bromoform in the Pacific we closer look at data from four cruises in the eastern Pacific (Blast 1, Gas Ex 98, Phase 1-04, RB-99-06: Figs. S26-S33; Butler et al., 2007) and one cruise in the western Pacific (TransBrom: Figs. S3435; Ziska et al., 2013); please that note overlaps exist. Sim- 
ulated concentrations in the northwestern Pacific in autumn represent observations during RB-99-06 very well (between 2 and $10 \mathrm{pmolL}^{-1}$ ), apart from underestimations close to the coast (Fig. S32). In spring-summer, concentrations in the model along the same track (Gas Ex 98) are 3 times higher than observations at some locations (Fig. S28), likely because primary production is overestimated by the model (Fig. S29). Similar mismatches of simulated and observed concentrations due to too high primary production in the model also show up in the equatorial Pacific when comparing to Phase 1-04 (Figs. S30, S31) in spring/early summer. In the eastern tropical Pacific, overestimations of the primary production can be linked to a commonly known weakness of most biogeochemistry models, the so-called "nutrient trapping" in the equatorial Pacific (details in Dietze and Loeptien, 2013), where too high nutrient concentrations at the surface lead to too high primary and export production. For both the northern and the equatorial eastern Pacific, bromoform concentrations in autumn and winter match observations well (Blast 1, Fig. S26; RB-99-06, Fig. S32). As the $\mathrm{CHBr}_{3}$ concentrations are overestimated in spring during highest bromoform production, the underestimation in later months indicates that the too strong source is compensated for by a strong sink, e.g. strong outgassing. In the western Pacific only data from the TransBrom cruise are available to compare simulated and observed concentrations. Simulated bromoform concentrations are almost identical in all experiments and closely match observations in the open ocean. Close to the Indonesian Shelf, simulated concentrations are underestimated compared to observations, probably because of macroalgae or other coastal sources, which are not implemented in the model.

\section{Southern Ocean and Arctic}

The comparison of HAMOCC-simulated primary production to the that derived by the VGPM model shows that NPP is overestimated in austral summer (Fig. S3) along several ship tracks (ADOX, Figs. S44-45; CLIVAR01, Figs. S40-41; SWEDARP, Figs. S36-37). The representation of primary production by satellite-based estimates (including VGPM) is poor in the Southern Ocean (Strutton et al., 2012). However, the overestimation of NPP could also indicate shortcomings of the biogeochemistry model, e.g. that iron limitation is not strong enough, as iron is the limiting nutrient for phytoplankton growth in this region or that there is too strong mixing in the physical model. For the Southern Ocean it is difficult to directly conclude from deviations between simulated and observed NPP about the quality of simulated bromoform. For example, overestimations in NPP do not always go in line with an overestimation of bromoform concentrations (e.g. S44 for ADOX). Apparently other parameters such as mixing have a strong impact on concentration patterns, too. This can be also seen for SWEDARP (Fig. S36; Abrahamsson et al., 2004), where bromoform concentrations do not follow the pattern of primary productivity or chlorophyll in both model results and observations. However, there are also examples of a good model representation of observed bromoform concentrations and primary production, i.e. for BLAST3 (FebruaryApril, Figs. S38-39) and CLIVAR01 (October-November, Figs. S40-41; 140-250 ${ }^{\circ}$ E).

As noted in Sect. 3.1, production of bromoform within sea ice by ice algae is not represented in the model. Therefore, open ocean $\mathrm{CHBr}_{3}$ concentrations downstream of melting sea ice and close to sea ice are likely to be underestimated. Furthermore, the contribution of uptake from the atmosphere to bromoform sources is large in polar regions (e.g. around the Antarctic Peninsula) and atmospheric boundary conditions rely on extrapolation of very sparse data. Therefore, we can not expect to simulate seawater bromoform concentrations in polar regions correctly. For this reason, the evaluation of Southern Ocean bromoform concentrations is only of preliminary nature and the detailed evaluation of bromoform concentrations in the Arctic is omitted. However, for completeness a figure showing bromoform concentrations in the Arctic compared to observations from a ship cruise in June 2002 can be found in the Supplement (Figs. S52 and S53).

\section{Summary}

Overall the model is capable of representing large-scale features of observed bromoform concentrations, considering that no tuning of the model is performed. Discrepancies mostly arise from regionally weak representation of primary production or insufficient representation of environmental conditions during the ship cruises in this nonhistorical present-day model configuration. Note that we compare monthly mean model output to observations along ship tracks, which usually lasted a couple of weeks. We refrain from analysing temporally higher resolved model output, because the atmospheric bromoform concentrations used in the gas exchange do not resolve such high temporal variability. Differences among the model experiments are often smaller than differences between model results and observations. The best match with observations is achieved when either reducing the bulk bromoform production rate or considering different production rates for different phytoplankton groups (Fig. 6, S4-5). A reduced diatom bromoform production ratio slightly improves the representation of the bromoform concentrations in the Southern Hemisphere, while the concentrations in the Northern Hemisphere are better depicted for a reduced non-diatom bromoform production ratio.

\subsection{Gas exchange with the atmosphere}

Simulated bromoform emissions follow a pronounced seasonal cycle, dictated by seawater concentrations and meteorological conditions. High emissions $\left(>1200 \mathrm{pmol} \mathrm{m}^{-2} \mathrm{~h}^{-1}\right.$ ) occur in regions of high bromoform production, i.e. in bo- 


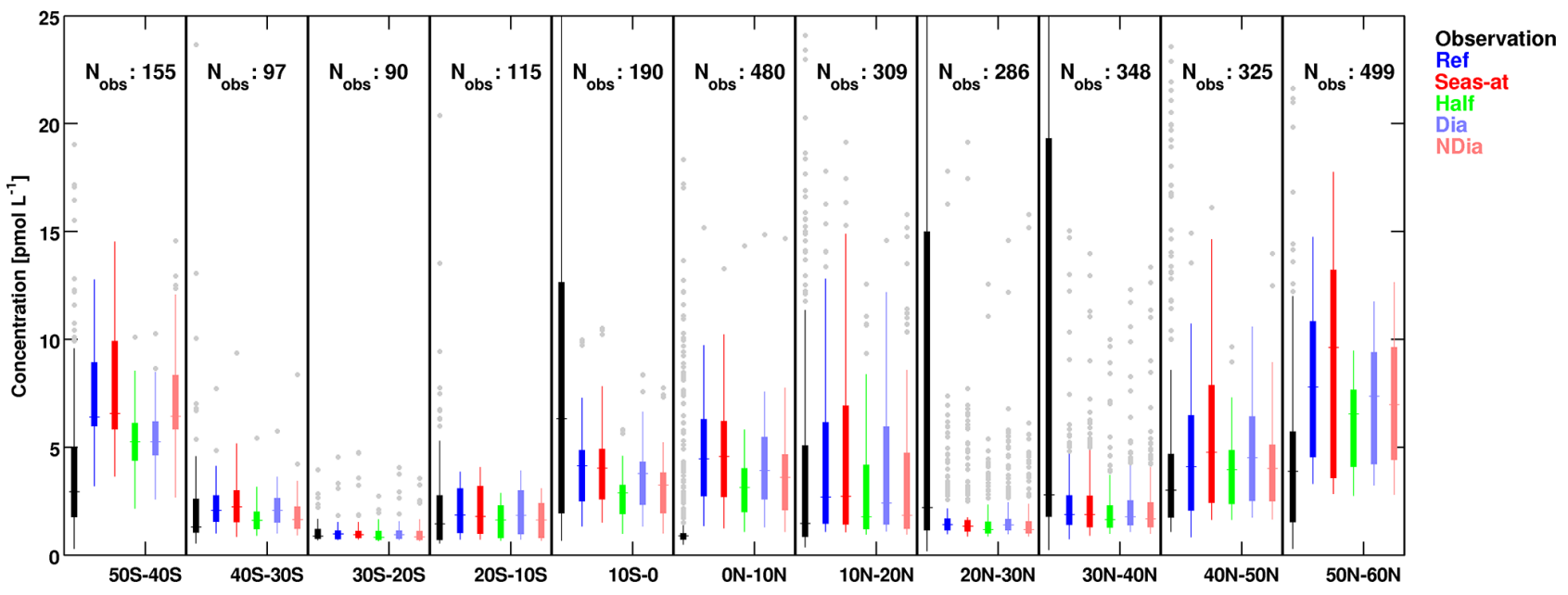

Figure 6. Box-and-whisker plot of simulated and observed surface ocean bromoform concentrations (pmol L ${ }^{-1}$ ). Box widths are determined by the 25 th and 75 th percentiles of data within each $10^{\circ}$ latitude box, outliers (grey) are located outside 1.5 times the differences of the percentiles, and the middle line of each box shows the median. Simulated concentrations are averaged over one grid cell around the location of observations. Different colours denote different experiments (Ref: blue; Seas-at: red; Half: green; Dia: pale purple; NDia: pale red); observations are shown in black.

real winter (DJF) in the Southern Ocean (Fig. 7a) and in boreal summer (JJA) in the North Pacific and the Atlantic Ocean (Fig. 7e). In contrast, in the oligotrophic subtropical gyres, bromoform emissions are low but still positive, i.e. into air $\left(<50 \mathrm{pmol} \mathrm{m}^{-2} \mathrm{~h}^{-1}\right)$. Tropical upwelling regions always show high emissions, as bromoform production is high all year. In the Southern Ocean and the northern North Atlantic, emissions in local winter seasons, as well as Arctic emissions, are characterized by net uptake from the atmosphere. In the latter two regions this feature also persists in the annual mean. In the Southern Ocean, high emissions in summer compensate for the uptake in winter, and over the year the ocean is a net source to the atmosphere. Also, at the global scale, the open ocean is a bromoform source to the atmosphere, and delivers approximately $0.9 \mathrm{Gmol} \mathrm{Bryr}^{-1}$ (Table 3). For the North Atlantic and the Arctic Ocean, the experiment Coast suggests that coastal sources could enhance oceanic concentrations and counteract the undersaturation of the ocean. Furthermore, in the Arctic and Southern Ocean, bromoform production in sea ice could have a similar effect with an increased sea-air flux, a feature that is also not resolved in the model. Both mechanisms are currently not included but would lead to higher simulated global bromoform emissions. In addition, the seasonal reversal of gas exchange is also strongly influenced by the atmospheric boundary conditions. Thus, it is important to choose these carefully for simulating realistic bromoform emissions with a stand-alone ocean model.

Generally, simulated emissions are higher in the extratropics of the Southern Hemisphere than those of the Northern Hemisphere (Fig. 8). Note that we choose a different unit here than in the residual discussion of gas ex- change to ease the comparison with the recent evaluation of $\mathrm{CHBr}_{3}$ emission inventories by Hossaini et al. (2013), who showed a similar figure. Zonal maxima are higher than $0.8 \times 10^{-13} \mathrm{~kg} \mathrm{~m}^{-2} \mathrm{~s}^{-1}$ in the southern extratropics compared to $0.4 \times 10^{-13} \mathrm{~kg} \mathrm{~m}^{-2} \mathrm{~s}^{-1}$ in the tropics (not shown). This pattern is different from the distribution often used in atmospheric chemistry modelling that shows largest emissions from the tropical oceans (Quack et al., 2004; Warwick et al., 2006; Sousa Santos and Rast, 2013). Lowest emissions are simulated in experiments Half and Dia due to the lower bromoform production (Table 2). In these experiments the relative contribution of the Northern and Southern Hemisphere to total emissions is similar. Compared to Half, emissions in the lower latitudes in Dia are higher because of low diatom presence.

Previous estimates of global annual marine bromoform emissions range from 1.5 to $10.3 \mathrm{GmolBryr}^{-1}$ (Table 3), considering either both coastal and open ocean regions or treating them individually. Most of these global estimates (except Palmer and Reason, 2009) are derived from indirect methods. This means that either bromoform measured in the marine boundary layer during ship cruises is used to calculate local fluxes which are extrapolated to the global scale (Butler et al., 2007; Ziska et al., 2013) or that emissions needed as boundary conditions in atmospheric modelling studies are constrained to lead to least deviation of simulated air concentrations from observations (e.g. Warwick et al., 2006; Liang et al., 2010; Sousa Santos and Rast, 2013). In the latter so-called "top-down" approach, the estimates are all based on the same concept; the global ocean is split into latitudinal bands for which different emissions are applied. However, the number and extent of these zones, the 


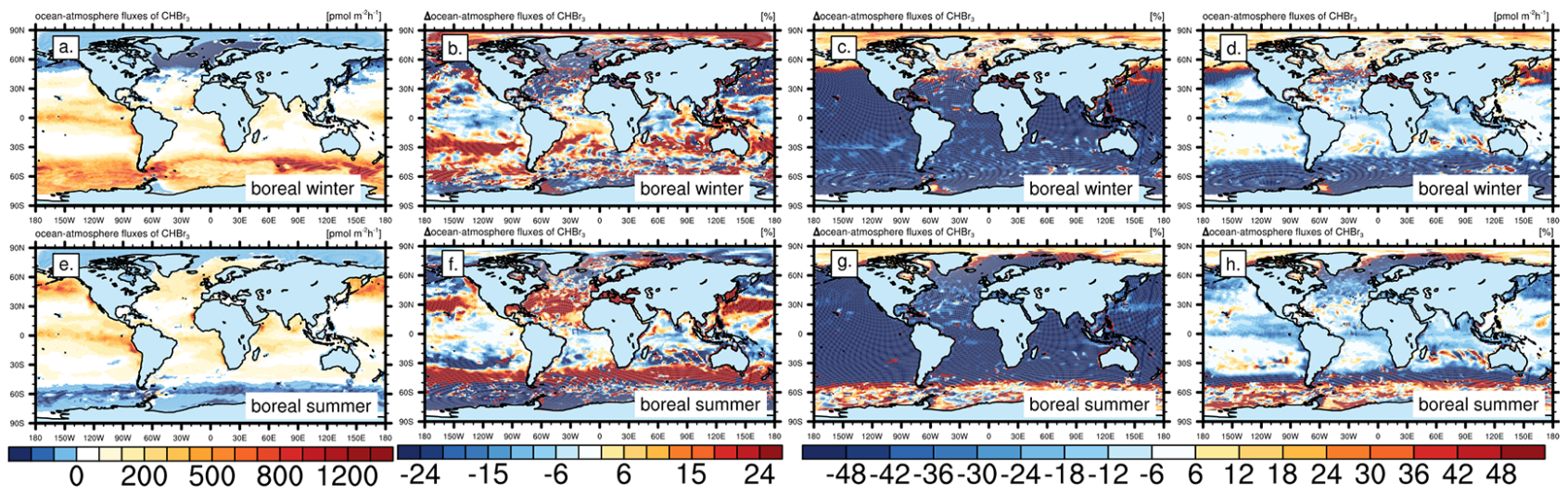

Figure 7. Mean bromoform sea-air flux $\left(\mathrm{pmol} \mathrm{m}^{-2} \mathrm{~h}^{-1}\right)$ in experiment Ref in boreal winter (a) and boreal summer (e) and the percentage difference (e.g. $\left.100 \cdot \frac{\text { Seas-at-Ref }}{\text { Ref }}\right)$ of Seas-at $(\mathbf{b}, \mathbf{f})$, Half $(\mathbf{c}, \mathbf{g})$, and Dia $(\mathbf{d}, \mathbf{h})$ in the same season.
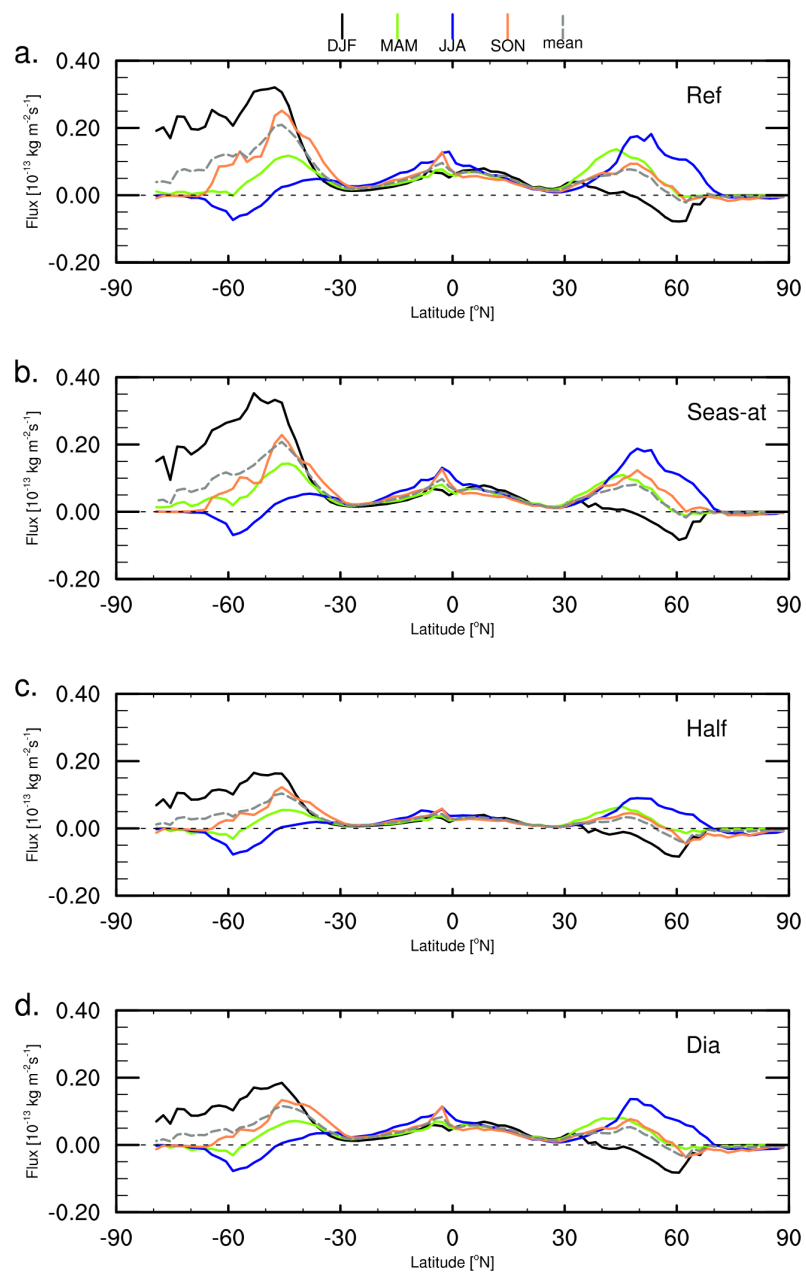

Figure 8. Zonal median of bromoform sea-air flux $\left(\mathrm{kg} \mathrm{m}^{-2} \mathrm{~s}^{-1}\right)$; mean of JJA (blue), DJF (black), MAM (green), and SON (orange); and annual mean (dashed grey). Results are from Ref (a), Seas-at (b), and Half (c), and Dia (d).
Table 3. Previously reported and simulated global annual bromoform net emissions $\left(\mathrm{GmolBryr}^{-1}\right)$ from the ocean.

\begin{tabular}{lll}
\hline Source type & Lit. value & Reference \\
\hline Open ocean & $10.01(3-22)$ & Quack and Wallace (2003) \\
& 10.26 & Yokouchi et al. (2005) \\
& $4.75-7.06$ & Warwick et al. (2006) \\
Global ocean & 10.0 & Butler et al. (2007) \\
Open ocean & 1.9 & Butler et al. (2007) \\
& 10.3 & O'Brien et al. (2013) \\
Tropics & 4.35 & Palmer and Reason (2009) \\
Global ocean & 5.31 & Liang et al. (2010) \\
Open ocean & 3.19 & Liang et al. (2010) \\
& 6.33 & Ordóñez et al. (2012) \\
Global ocean & 2.49 & Ziska et al. (2013) (OLS) \\
Global ocean & 1.5 & Ziska et al. (2013) (RF) \\
Global ocean & 3.5 & Sousa Santos (2009) \\
Open ocean & 0.9 & Sousa Santos and Rast (2013) \\
\hline
\end{tabular}

treatment of the tropics and coastal regions, and the temporal resolution considered differ among the different studies. As mentioned above, Hossaini et al. (2013) performed a detailed evaluation of global bromoform emission inventories for atmospheric modelling. They include three top-down inventories (Warwick et al., 2006; Liang et al., 2010; Ordóñez et al., 2012), as well as the bottom-up (based on observations in air and water) inventory by Ziska et al. (2013) based on the OLS method. The only inventory used in the study of Hossaini et al. (2013) that considers temporal variability in the emissions is the one by Ordóñez et al. (2012). They indirectly resolve seasonally varying bromoform fluxes within the tropics $\left( \pm 20^{\circ}\right)$ because they relate air-sea fluxes to satellitebased chlorophyll concentrations which are in turn temporally variable. Hossaini et al. (2013) are, however, able to reproduce most of the seasonality of bromoform atmospheric mixing ratios even with the temporally invariant emissions. 
They argue that this is presumably because the seasonality is driven by photolytic degradation in air. The seasonality in our simulated emissions sometimes encompasses a variation of more than a factor of 2 , in particular in the productive extratropical regions. The impact of this seasonality on the evolution of atmospheric mixing ratios needs to be tested in dynamic ocean-atmosphere coupling. In Hossaini et al. (2013), good agreement between observed and simulated atmospheric mixing ratios, in particular within the tropics, could be achieved when using the emission inventory by Ziska et al. (2013), which was the lowest of the previous estimates (Table 3). Therefore, we will focus on the comparison of our results with those of that inventory. Our open ocean emissions are even lower than this observation-based estimate by Ziska et al. (2013). Our approaches differ in the oceanic concentrations that drive the saturation anomaly. Our simulated ocean concentrations represent the observations used in the extrapolation by Ziska et al. (2013) well, with a tendency towards overestimating seawater concentrations (Sect. 3.2). Global fluxes are lower in our approach for several reasons. First, our model considers the seasonality of oceanic concentrations in contrast to Ziska et al. (2013). Simulated concentrations match observations well; however, they are often lower in the winter season, for which observations are rare. Furthermore, we do not include (and do not intend to represent) coastal emissions, which are generally higher than open ocean emissions. Another reason why our global emissions are lower than the ones in Ziska et al. (2013) is that their high emissions often occur in locations where no data exist as a result from the extrapolation method used, e.g. in the northern North Atlantic and in the subtropical eastern South Pacific. Our emissions indicate uptake from the atmosphere in the northern North Atlantic and the Gulf of Alaska and the Bering Sea in boreal winter (DJF) but fluxes into air in all other seasons, which leads to lower overall emissions. The only ship cruise in the subtropical eastern South Pacific is Blast 1, which does not show high concentrations close to $30^{\circ} \mathrm{S}$. Another region where our simulated fluxes deviate from the previous estimates is the subtropics. As primary production is low in subtropical gyres due to the nutrient limitation of plankton growth, $\mathrm{CHBr}_{3}$ emissions are also low, approximately one-third of the emissions by Liang et al. (2010) (compare Fig. 8 with Fig. 3 in Hossaini et al., 2013). However, modelled concentrations match observations well, i.e. in the subtropical Atlantic (e.g. compared to data from the Blast 2 cruise (Fig. S6; Butler et al., 2007), or data from the M60 cruise (Fig. S18; Ziska et al., 2013)). Thus, as gas exchange is the primary sink of ocean bromoform in this region, we have confidence in the simulated emissions.

\section{Conclusions}

Our global coupled ocean biogeochemistry model including bromoform is able to satisfactorily represent observed large- scale patterns of bromoform surface concentrations in the open ocean. At the global scale, bulk phytoplankton-based primary production appears to be a good proxy for simulating bromoform production in the open ocean. However, at the regional scale, fractionation of bromoform synthesis should be considered, e.g. with lower bromoform production by diatoms rather than by other phytoplankton groups in the Southern Hemisphere. In the subarctic and Arctic regions, bromoform formed in coastal regions can make a considerable contribution to open ocean bromoform concentrations. Bromoform emissions are characterized by large spatio-temporal variations and only partly follow the latitudinal distribution patterns as suggested by top-down approach. The open ocean is a smaller source of bromoform than indicated by previous studies. If a similar vertical transfer in the atmosphere is assumed, the Pacific likely delivers more to the upper atmosphere than the Atlantic or Indian Ocean, as the model predicts highest emissions from the tropical Pacific compared to other low-latitude regions. Particularly interesting are the large-scale patterns that indicate bromoform uptake from the atmosphere, which do not show up in climatological mean emissions. The robustness and implications of the flux reversal should be studied in more detail. In this regard, the model needs to be refined to also resolve coastal sources and bromoform production within sea ice. In addition to the global observation based emission climatology by Ziska et al. (2013), the simulated emissions describe realistic temporal features in the open ocean arising from bromoform production and thus can be used in atmospheric chemistry models that include bromine cycling.

\section{The Supplement related to this article is available online at doi:10.5194/bg-12-1967-2015-supplement.}

Acknowledgements. The authors are grateful to F. Ziska (Geomar, Helmholtz Centre for Ocean Research Kiel, Germany) for providing observational data and for valuable discussions. We furthermore thank Kirstin Krüger (Geomar, Helmholtz Centre for Ocean Research Kiel, now at University of Oslo, Norway), Helmke Hepach, and Susann Tegtmeier (both Geomar, Helmholtz Centre for Ocean Research Kiel, Germany) for discussing the model results with us. We thank Joachim Segschneider (Max Planck Institute for Meteorology, Hamburg, Germany) for internal review of the manuscript. Model simulations were performed with the IBM Power 6 supercomputer at the DKRZ (German Climate Computing Center). The study was funded through the German BMBF project SOPRAN (Surface Ocean Processes in the Anthropocene, SOPRAN III 03F0662E).

Edited by: G. Herndl 


\section{References}

Abrahamsson, K., Bertilsson, S., Chierici, S., Fransson, A., Froneman, P., Lorén, A., and Pakhomov, E.: Variations of biochemical parameters alonga transect in the Southern Ocean, with special emphasis on volatile halogenated organic compounds, Deep-Sea Res. Pt. II, 51, 2745-2756, 2004.

Allonier, A.-S., Khalanski, M., Camel, V., and Bermond, A.: Characterization of chlorination by-products in cooling effluents of coastal nuclear power stations, Mar. Pollut. Bull., 38, 1232-1241, doi:10.1016/S0025-326X(99)00168-X, 1999.

Aschmann, J., Sinnhuber, B.-M., Atlas, E. L., and Schauffler, S. M.: Modeling the transport of very short-lived substances into the tropical upper troposphere and lower stratosphere, Atmos. Chem. Phys., 9, 9237-9247, doi:10.5194/acp-9-9237-2009, 2009.

Behrenfeld, M. and Falkowski, P.: Photosynthetic rates derived from satellite-based chlorophyll concentration, Limnol. Oceanogr., 42, $1-20,1997$.

Behringer, D. and Xue, Y.: Evaluation of the global ocean data assimilation system at NCEP: The Pacific Ocean, in: Eighth Symposium on Integrated Observing and Assimilation Systems for Atmosphere, Oceans, and Land Surface, AMS 84th Annual Meeting, Washington State Convention and Trade Center, Seattle, Washington, 11-15 January 2004, Session 2, Ocean Observations, Monday, 12 January 2004, available at: https://ams.confex. com/ams/84Annual/techprogram/paper_70720.htm (last access: 29 October 2014), 2004.

Beyersdorf, A. J., Blake, D. R., Swanson, A., Meinardi, S., Rowland, F., and Davis, D.: Abundances and variability of tropospheric volatile organic compounds at the South Pole and other Antarctic locations, Atmos. Environ., 44, 4565-4574, doi:10.1016/j.atmosenv.2010.08.025, 2010.

Bondu, S., Cocquempot, B., Deslandes, E., and Morin, P.: Effects of salt and light stress on the release of volatile halogenated organic compounds by Solieria chordalis: A laboratory incubation study, Botanica Marina, 51, 485-492, 2008.

Bracher, A., Vountas, M., Dinter, T., Burrows, J. P., Röttgers, R., and Peeken, I.: Quantitative observation of cyanobacteria and diatoms from space using PhytoDOAS on SCIAMACHY data, Biogeosciences, 6, 751-764, doi:10.5194/bg-6-751-2009, 2009.

Butler, J., King, D., Lobert, J., Montzka, S., Yvon-Lewis, S., Hall, B., Warwick, N., Mondell, D., Aydin, M., and Elkins, J.: Oceanic distributions and emissions of shortlived halocarbons, Global Biogeochem. Cy., 21, GB1023, doi:10.1029/2006GB002732, 2007.

Carpenter, L. and Liss, P.: On temperate sources of bromoform and other reactive organic bromine gases, J. Geophys. Res.-Atmos., 105, 20539-20547, 2000.

Carpenter, L. J., Jones, C. E., Dunk, R. M., Hornsby, K. E., and Woeltjen, J.: Air-sea fluxes of biogenic bromine from the tropical and North Atlantic Ocean, Atmos. Chem. Phys., 9, 1805-1816, doi:10.5194/acp-9-1805-2009, 2009.

Carr, M.-E., Friedrichs, M. A., Schmeltz, M., Aita, M. N., Antoine, D., Arrigo, K. R., Asanuma, I., Aumont, O., Barber, R., Behrenfeld, M., Bidigare, R., Buitenhuis, E. T., Campbell, J., Ciotti, A., Dierssen, H., Dowell, M., Dunne, J., Esaias, W., Gentili, B., Gregg, W., Groom, S., Hoepffner, N., Ishizaka, J., Kameda, T., Quéré, C. L., Lohrenz, S., Marra, J., Mélin, F., Moore, K., Morel, A., Reddy, T. E., Ryan, J., Scardi, M., Smyth, T., Turpie, K., Tilstone, G., Waters, K., and Ya- manaka, Y.: A comparison of global estimates of marine primary production from ocean color, Deep-Sea Res. Pt. II, 53, 741-770, doi:10.1016/j.dsr2.2006.01.028, 2006.

Chuck, A., Turner, S., and Liss, P.: Oceanic distributions and airsea fluxes of biogenic halocarbons in the open ocean, J. Geophys. Res.-Oceans, 110, 1-12, 2005.

Colomb, A., Yassaa, N., Williams, J., Peeken, I., and Lochte, K.: Screening volatile organic compounds (VOCs) emissions from five marine phytoplankton species by head space gas chromatography/mass spectrometry (HS-GC/MS), J. Environ. Monitor., 10, 325-330, 2008.

Dietze, H. and Loeptien, U.: Revisiting "nutrient trapping” in global coupled biogeochemical ocean circulation models, Global Biogeochem. Cy., 27, 265-284, doi:10.1002/gbc.20029, 2013.

Geen, C.: Selected Marine Sources and Sinks of Bromoform and Other Low Molecular Weight Organobromines, M.S. thesis, Dalhousie University, Halifax, Nova Scotia, Canada, 1992.

Granfors, A., Karlsson, A., Mattsson, E., Smith, W. O., and Abrahamsson, K.: Contribution of sea ice in the Southern Ocean to the cycling of volatile halogenated organic compounds, Geophys. Res. Lett., 40, 3950-3955, doi:10.1002/grl.50777, 2013.

Gregg, W. W. and Casey, N. W.: Modeling coccolithophores in the global oceans, Deep-Sea Res. Pt. II, 54, 447-477, doi:10.1016/j.dsr2.2006.12.007, 2007.

Hense, I. and Quack, B.: Modelling the vertical distribution of bromoform in the upper water column of the tropical Atlantic Ocean, Biogeosciences, 6, 535-544, doi:10.5194/bg-6-535-2009, 2009.

Hossaini, R., Chipperfield, M. P., Monge-Sanz, B. M., Richards, N. A. D., Atlas, E., and Blake, D. R.: Bromoform and dibromomethane in the tropics: a 3-D model study of chemistry and transport, Atmos. Chem. Phys., 10, 719-735, doi:10.5194/acp-10-719-2010, 2010.

Hossaini, R., Mantle, H., Chipperfield, M. P., Montzka, S. A., Hamer, P., Ziska, F., Quack, B., Krüger, K., Tegtmeier, S., Atlas, E., Sala, S., Engel, A., Bönisch, H., Keber, T., Oram, D., Mills, G., Ordóñez, C., Saiz-Lopez, A., Warwick, N., Liang, Q., Feng, W., Moore, F., Miller, B. R., Marécal, V., Richards, N. A. D., Dorf, M., and Pfeilsticker, K.: Evaluating global emission inventories of biogenic bromocarbons, Atmos. Chem. Phys., 13, 11819-11838, doi:10.5194/acp-1311819-2013, 2013.

Hughes, C., Johnson, M., Utting, R., Turner, S., Malin, G., Clarke, A., and Liss, P.: Microbial control of bromocarbon concentrations in coastal waters of the western Antarctic Peninsula, Mar. Chem., 151, 35-46, 2013.

Ilyina, T., Six, K. D., Segschneider, J., Maier-Reimer, E., Li, H., and Núñez-Riboni, I.: Global ocean biogeochemistry model HAMOCC: Model architecture and performance as component of the MPI-Earth system model in different CMIP5 experimental realizations, J. Adv. Model. Earth Syst., 5, 287-315, doi:10.1029/2012MS000178, 2013.

Karlsson, A., Auer, N., Schulz-Bull, D., and Abrahamsson, K.: Cyanobacterial blooms in the Baltic - a source of halocarbons, Mar. Chem., 110, 129-139, 2008.

Kloster, S., Feichter, J., Maier-Reimer, E., Six, K. D., Stier, P., and Wetzel, P.: DMS cycle in the marine ocean-atmosphere system a global model study, Biogeosciences, 3, 29-51, doi:10.5194/bg3-29-2006, 2006. 
Laturnus, F.: Marine macroalgae in polar regions as natural sources for volatile organohalogens, Environ. Sci. Pollut. R., 8, 103-108, 2001

Law, K. and Sturges, W.: Halogenated very short-lived substances, Chapter 2, in: Scientific Assessment of Ozone Depletion: 2006, WMO, Geneva, Report No. 50, 2007.

Leblanc, K., Arístegui, J., Armand, L., Assmy, P., Beker, B., Bode, A., Breton, E., Cornet, V., Gibson, J., Gosselin, M.-P., Kopczynska, E., Marshall, H., Peloquin, J., Piontkovski, S., Poulton, A. J., Quéguiner, B., Schiebel, R., Shipe, R., Stefels, J., van Leeuwe, M. A., Varela, M., Widdicombe, C., and Yallop, M.: A global diatom database - abundance, biovolume and biomass in the world ocean, Earth Syst. Sci. Data, 4, 149-165, doi:10.5194/essd-4-149-2012, 2012.

Leedham, E. C., Hughes, C., Keng, F. S. L., Phang, S.-M., Malin, G., and Sturges, W. T.: Emission of atmospherically significant halocarbons by naturally occurring and farmed tropical macroalgae, Biogeosciences, 10, 3615-3633, doi:10.5194/bg10-3615-2013, 2013.

Liang, Q., Stolarski, R. S., Kawa, S. R., Nielsen, J. E., Douglass, A. R., Rodriguez, J. M., Blake, D. R., Atlas, E. L., and Ott, L. E.: Finding the missing stratospheric $\mathrm{Br}_{\mathrm{y}}$ : a global modeling study of $\mathrm{CHBr}_{3}$ and $\mathrm{CH}_{2} \mathrm{Br}_{2}$, Atmos. Chem. Phys., 10, 2269-2286, doi:10.5194/acp-10-2269-2010, 2010.

Lin, C. and Manley, S.: Bromoform production from seawater treated with bromoperoxidase, Limnol. Oceanogr., 57, 18571866, 2012.

Liu, Y., Yvon-Lewis, S. A., Hu, L., Salisbury, J. E., and O’Hern, J. E.: $\mathrm{CHBr}_{3}, \mathrm{CH}_{2} \mathrm{Br}_{2}$, and $\mathrm{CHClBr}_{2}$ in US coastal waters during the Gulf of Mexico and East Coast Carbon cruise, J. Geophys. Res., 116, C10004, doi:10.1029/2010JC006729, 2011.

Manley, S., Goodwin, K., and North, W.: Laboratory production of bromoform, methylene bromide, and methyl-iodide by macroalgaw in the nearshore southern California waters, Limnol. Oceanogr., 37, 1652-1659, 1992.

Marsland, S., Haak, H., Jungclaus, J., Latif, M., and Röske, F.: The Max-Planck-Institute global ocean/sea ice model with orthogonal curvilinear coordinates, Ocean Model., 5, 91-127, 2003.

Mattson, E., Karlsson, A., Smith, W., and Abrahamsson, K.: The relationship between biophysical variables and halocarbon distributions in the waters of the Amundsen and Ross Seas, Antarctica, Mar. Chem., 140-141, 1-9, 2012.

Moore, R. and Tokarczyk, R.: Volatile biogenic halocarbons in the northwest Atlantic, Global Biogeochem. Cy., 7, 195-210, 1993.

Moore, R., Geen, C., and Tait, V.: Determination of Henry's law constants for a suite of naturally occurring halogenated methanes in seawater, Chemosphere, 30, 1183-1191, 1995.

Moore, R., Webb, M., Tokarczyk, R., and Wever, R.: Bromoperoxidase and iodoperoxidase enzymes and production of halogenated methanes in marine diatom cultures, J. Geophys. Res.-Oceans, 101, 20899-20908, doi:10.1029/96JC01248, 1996.

Moortgat, G., Meller, R., and Schneider, W.: Temperature dependence $(256-296 \mathrm{~K})$ of the absorption cross sections of bromoform in the wavelength range $285-360 \mathrm{~nm}$, in: The Tropospheric Chemistry of Ozone in the Polar Regions, Springer Berlin Heidelberg, 359-370, doi:10.1007/978-3-642-78211-4, 1993.

Nightingale, P. D., Malin, G., Law, C., Watson, A., Liss, P., Liddicoat, M., Boutin, J., and Upstill-Goddard, R.: In situ evaluation of air-sea gas exchange parameterizations using novel conserva- tive and volatile tracers, Global Biogeochem. Cy., 14, 373-387, 2000.

O’Brien, L. M., Harris, N. R. P., Robinson, A. D., Gostlow, B., Warwick, N., Yang, X., and Pyle, J. A.: Bromocarbons in the tropical marine boundary layer at the Cape Verde Observatory - measurements and modelling, Atmos. Chem. Phys., 9, 9083-9099, doi:10.5194/acp-9-9083-2009, 2009.

O’Brien, C. J., Peloquin, J. A., Vogt, M., Heinle, M., Gruber, N., Ajani, P., Andruleit, H., Arístegui, J., Beaufort, L., Estrada, M., Karentz, D., Kopczyńska, E., Lee, R., Poulton, A. J., Pritchard, T., and Widdicombe, C.: Global marine plankton functional type biomass distributions: coccolithophores, Earth Syst. Sci. Data, 5, 259-276, doi:10.5194/essd-5-259-2013, 2013.

Ordóñez, C., Lamarque, J.-F., Tilmes, S., Kinnison, D. E., Atlas, E. L., Blake, D. R., Sousa Santos, G., Brasseur, G., and Saiz-Lopez, A.: Bromine and iodine chemistry in a global chemistry-climate model: description and evaluation of very short-lived oceanic sources, Atmos. Chem. Phys., 12, 14231447, doi:10.5194/acp-12-1423-2012, 2012.

Palmer, C. and Reason, C.: Relationships of surface bromoform concentrations with mixed layer depth and salinity in the tropical oceans, Global Biogeochem. Cy., 23, GB2014, doi:10.1029/2008GB003338, 2009.

Paul, C. and Pohnert, G.: Production and role of volatile halogenated compounds from marine algae, Nat. Prod. Rep., 28, 186195, doi:10.1039/c0np00043d, 2011.

Quack, B. and Wallace, D.: Air-sea flux of bromoform: controls, rates, and implications, Global Biogeochem. Cy., 17, 1023, doi:10.1029/2002GB001890, 2003.

Quack, B., Atlas, E., Petrick, G., Stroud, V., Schauffler, S., and Wallace, D.: Oceanic bromoform sources for the tropical atmosphere, Geophys. Res. Lett., 31, 1-4, 2004.

Roy, R. N., Roy, L. N., Vogel, K. M., Porter-Moore, C., Pearson, T., Good, C. E., Millero, F. J., and Campbell, D. M.: The dissociation constants of carbonic acid in seawater at salinities 5 to 45 and temperatures 0 to $45^{\circ} \mathrm{C}$, Mar. Chem., 44, 249-267, 1993.

Saiz-Lopez, A., Lamarque, J.-F., Kinnison, D. E., Tilmes, S., Ordóñez, C., Orlando, J. J., Conley, A. J., Plane, J. M. C., Mahajan, A. S., Sousa Santos, G., Atlas, E. L., Blake, D. R., Sander, S. P., Schauffler, S., Thompson, A. M., and Brasseur, G.: Estimating the climate significance of halogen-driven ozone loss in the tropical marine troposphere, Atmos. Chem. Phys., 12, 3939-3949, doi:10.5194/acp-12-3939-2012, 2012.

Salawitch, R.: Atmospheric chemistry: biogenic bromine, Nature, 439, 275-277, 2006.

Sayavedra-Soto, L., Gvakharia, B., Bottomley, P., Arp, D., and Dolan, M.: Nitrification and degradation of halogenated hydrocarbons-a tenuous balance for ammonia-oxidizing bacteria, Appl. Microbiol. Biot., 86, 435-444, 2010.

Schall, C., Heumann, K., and Kirst, G.: Biogenic volatile organoiodine and organobromine hydrocarbons in the Atlantic Ocean from $42^{\circ} \mathrm{N}$ to $72^{\circ} \mathrm{S}$, Fresen. J. Anal. Chem., 359, 298-305, 1997.

Sousa Santos, G.: The Effect of Halogens on global tropospheric Ozone, Reports on Earth System Science, 59, available at: http://www.mpimet.mpg.de/fileadmin/publikationen/Reports/ WEB_BzE_59.pdf (last access: 20 March 2015), 2009.

Sousa Santos, G. and Rast, S.: A global model study of natural bromine sources and the effects on tropospheric chemistry using 
MOZART4, J. Atmos. Chem., 70, 69-89, doi:10.1007/s10874013-9252-y, 2013.

Strutton, P., Lovenduski, N., Mongin, M., and Matear, R.: Quantification of Southern Ocean phytoplankton biomass and primary productivity via satellite observations and biogeochemical models, CCAMLR Sci., 19, 247-265, 2012.

Tegtmeier, S., Krüger, K., Quack, B., Atlas, E. L., Pisso, I., Stohl, A., and Yang, X.: Emission and transport of bromocarbons: from the West Pacific ocean into the stratosphere, Atmos. Chem. Phys., 12, 10633-10648, doi:10.5194/acp-1210633-2012, 2012.

Umlauf, L., Burchard, H., and Bolding, K.: GOTM - scientific documentation: version 3.2, Marine Science Reports, 63, 1-346, 2005.

Warwick, N. J., Pyle, J. A., Carver, G. D., Yang, X., Savage, N. H., O'Connor, F. M., and Cox, R. A.: Global modeling of biogenic bromocarbons, J. Geophys. Res.-Atmos., 111, D24305, doi:10.1029/2006JD007264, 2006.

Washington, J. W.: Hydrolysis rates of dissolved volatile organic compounds: principles, temperature effects and literature review, Ground Water, 33, 415-424, doi:10.1111/j.17456584.1995.tb00298.x, 1995.

Westberry, T., Behrenfeld, M. J., Siegel, D. A., and Boss, E.: Carbon-based primary productivity modeling with vertically resolved photoacclimation, Global Biogeochem. Cy., 22, GB2024, doi:10.1029/2007GB003078, 2008.
Wever, R. and van der Horst, M. A.: The role of vanadium haloperoxidases in the formation of volatile brominated compounds and their impact on the environment, Dalton T., 42, 11778-11786, doi:10.1039/C3DT50525A, 2013.

Yokouchi, Y., Hasebe, F., Fujiwara, M., Takashima, H., Shiotani, M., Nishi, N., Kanaya, Y., Hashimoto, S., Fraser, P., ToomSauntry, D., Mukai, H., and Nojiri, Y., Correlations and emission ratios among bromoform, dibromochloromethane, and dibromomethane in the atmosphere, J. Geophys. Res., 110, D23309, doi:10.1029/2005JD006303, 2005.

Ziska, F., Quack, B., Abrahamsson, K., Archer, S. D., Atlas, E., Bell, T., Butler, J. H., Carpenter, L. J., Jones, C. E., Harris, N. R. P., Hepach, H., Heumann, K. G., Hughes, C., Kuss, J., Krüger, K., Liss, P., Moore, R. M., Orlikowska, A., Raimund, S., Reeves, C. E., Reifenhäuser, W., Robinson, A. D., Schall, C., Tanhua, T., Tegtmeier, S., Turner, S., Wang, L., Wallace, D., Williams, J., Yamamoto, H., Yvon-Lewis, S., and Yokouchi, Y.: Global sea-to-air flux climatology for bromoform, dibromomethane and methyl iodide, Atmos. Chem. Phys., 13, 8915-8934, doi:10.5194/acp-13-8915-2013, 2013. 